\title{
Analysis of the science development of the PST - CCE in applied undergraduate colleges and universities
}

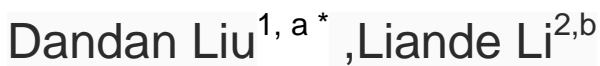 \\ ${ }^{1}$ Wutong street no. 2 in sujiatun district of shenyang,liaoning province,china \\ ${ }^{2}$ Wutong street no. 2 in sujiatun district of shenyang,liaoning province,china \\ a29106350@qq.com
}

Keywords: PST - CCE; Talent training; Teaching reform; Scientific development; Professional Situational Teaching

\begin{abstract}
The PST - CCE English full name is "Professional Situational Teaching - Competency Centered Education ",it is "the formation post ability as the core of professional contextualized training mode". this pattern breaks the teacher's teaching way of past, Then forms "as the carrier, take the student as the main body, to project task for drive" mechanism, Cultivating students' independence, embarks from the interest in teaching mode, In order to service applied undergraduate colleges, cultivate excellent applied skilled personnel.

In view of China's current education background and social background, PST - CCE in personnel training mode should play a bigger role in undergraduate colleges and universities, And constantly innovation, makes the applied universities science get in continuous development, This article gives explain from the following several aspects .
\end{abstract}

\section{Simple analysis PST-CCE}

PST - CCE is "the formation post ability as the core of professional contextualized training mode". To deep understanding of PST - CCE, will know what is post ability, and how to build professional situation.

Post ability. Post ability refers to: the meaning of a particular task roles need to have the sum of the ability quality, It is proposed by the famous American organization behavior researchers David McClelland (David McClelland) as the concept of "ability quality", ability quality (Competency) is defined by McClelland as: Can make a clear distinction between the specific jobs and organizational environment, outstanding performance and general performance level of personal characteristics, Is divided into five levels:

(1) Knowledge

(2) Skill

(3) Self - Concept

(4) Traits

(5) Motives

McClelland uses iceberg theory, belong to the sea level of knowledge and skills is called a general quality (Threshold Competencies). But really can distinguish between men and deep reasons of common people, was lurking in the self concept, traits, motivation below sea level, These are known as the diagnostic quality (Differentiation Competencies), The formation post ability as the core shows that the cultivation of our purpose is to cultivate graduates who can adapt to the job, Shorten 
or even do not need time to adapt to the jobs, by identifying sex quality make it become the positions and competent.

Build professional situation. Building profession situation should follow the principle "task lead, service driven, target specific, practical content, do learn" , And tasks can be divided into cognitive tasks, experience, practice tasks and accomplish tasks four stages. Professional contextualized training mode, Use of teaching method is making the real professional scene and situation feed into our teaching, Let the students first perceived task in the process of learning, Through the process of learning experience and practice task, And finally completed the task, The whole process can make exert a subtle influence on students and make them feel the job requirements of the future career.

\section{The scientific development of Applied Undergraduate Colleges}

Firstly combined closely with the regional economic development, Track local colleges development, Don't aim high, just want to create "first-class", First of all should be willing to become the "local institutions", Consciously get into local economic and social development, and change many university on the condition of the local low development contribution rate.

Secondly explore a characteristic industry of colleges and universities, According to the special requirements of key industries, directional cultivating talents is the important path of seeking development, Such as the hotel management institute of Shenyang city university, The film and television media institute, And mechanical and electrical engineering institute has established the characteristic specialized subject, each teacher teaches students the skills of a characteristic teaching methods, enable students to master the core of this professional skills.

Thirdly adhere to the close combination between Production and research, Industry-university-institute cooperation in economy, technology and education integration development rule, is to improve the personnel training quality, and grasp the overall situation, the service for the development of economic and social. Colleges and universities should take education chain linkage industry chain, it can even build a workshop, a factory, a company, even in dry middle school, students are encouraged to learn and practice ${ }^{[1]}$.

\section{Teaching mode reform}

On the premise of meet the needs of society, We want to cultivate talents who have certain professional quality, Acquire a knowledge of skills, teamwork and cooperation spirit, has a master consciousness, can be independent of the graduates, In order to meet this requirement, we must work in PST - CCE teaching mode change as follows:

Change the way of teaching. The traditional teacher speak, students listen to; The knowledge cramming education, the student is not in heart, Interactive less, poor enthusiasm, passive learning situation should change to the new teaching methods. Starting from the interest of students, the use of situational teaching, project teaching method, task, teaching, case teaching method and comprehensive teaching means to arouse the enthusiasm of students, make students form the habit of active learning ${ }^{[2]}$.

In addition, we want to introduce a group teaching.Each group of 4 people, each person to perform different functions, plays a different role in the group. They can work together to complete a project.

With the "innovative teaching mode of hidden" layer, put an end to the traditional classroom teaching model, according to the unified standard, unified content, teaching schedule ; but 
the construction of "students' implicit 'hierarchical stratification the content of layered hierarchical evaluation layer to improve the teaching mode".As shown in the following figure.

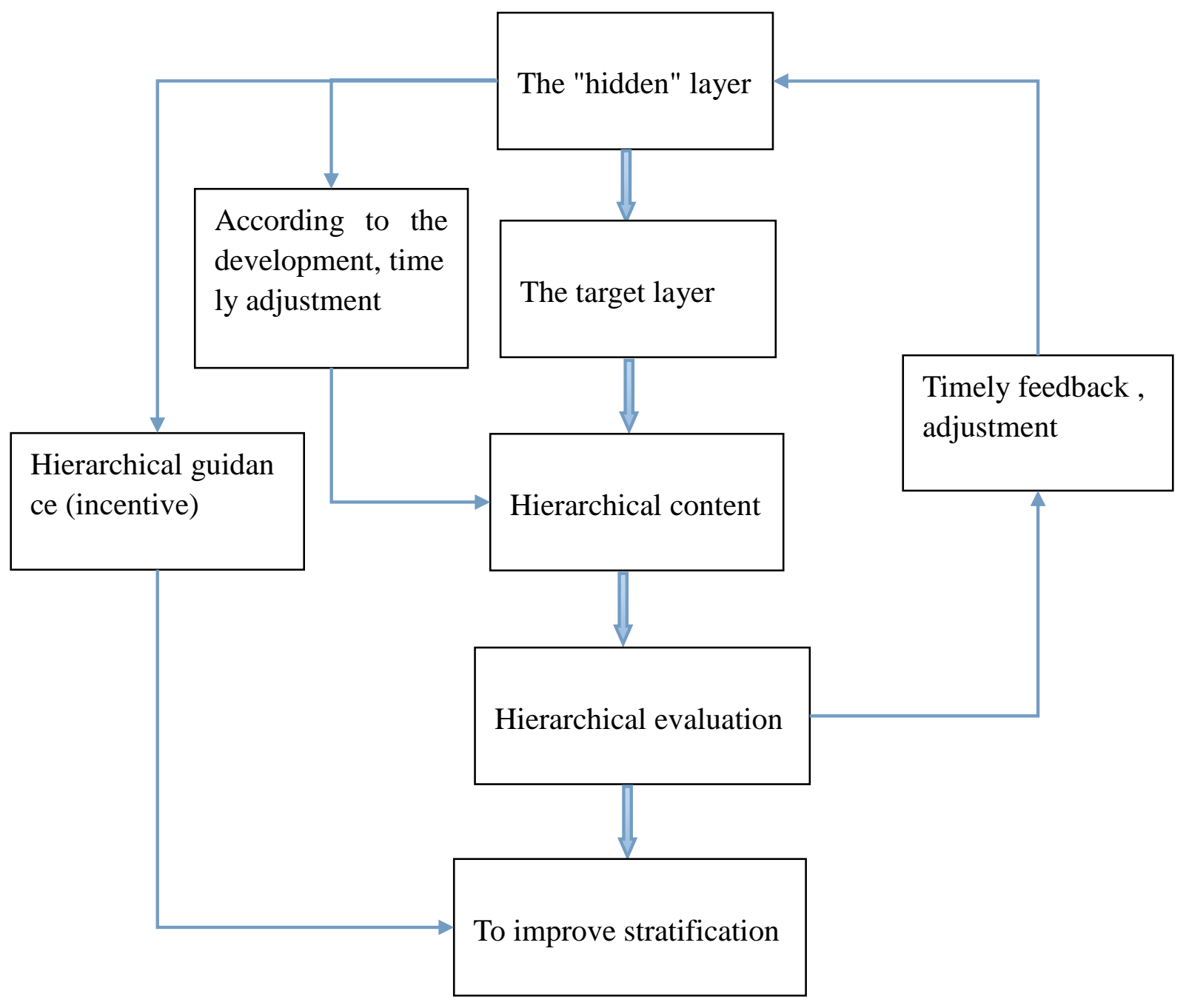

Figure. 1 "Invisible" layered graph

Change teaching place and means. The traditional teaching in the classroom or laboratory has become a law, Students have no new idea, some students even have psychological feeling bored at the sight of the teacher open the PPT (this is I do a weakened), The general courses this semester, originally very interesting content, but the students see is with PPT, no one to hear, cause the classroom discipline is very bad, A waste of the resources and time. We should be combined with the course content, location and timely transformation method.

Change the way of assessment. A youngster ancient, for the rapid development of modern society has long been misplaced, Should be to pass the final examination of the transformation for the combination of process inspection and final form. Process inspection notice at ordinary times of learning evaluation, the result to each student's true level. To eliminate the not learn at ordinary times, the phenomenon of the final up also get good grades. 


\section{References}

[1] Dandan Liu: Analysis the scientific development of private independent college transition; Liaoning Provincial Institute of Higher Education Conference (Shenyang, China, October 24, 2014) .

[2] Xue Jun: Try to talk about secondary vocational middle school mathematics in the real situation the construction of teaching design (New course (middle) historical period in 2008).

[3] Xiaoming Li: A Multidisciplined Teaching Reform of Biomaterials Course for Undergraduate Students; Journal of Science Education and Technology( Apr16, 2015).

[4]Junxing Zhang: 2012 International Workshop on Information and Electronics Engineering (Available online 15 February 2012)Volume 29, 2012, Pages 3679-3684.

[5]Joan E. Talbert: Professionalism and Politics in High School Teaching Reform; Journal of Educational Change (December 2002) Volume 3, Issue 3-4, pp 339-363.

[6]Hans-Joachim Vollrath: Towards an authentic teaching of mathematics: Hans-Georg Steiner's contribution to the reform of mathematics teaching; ZDM(15 Feb 2007)Volume 39, Issue 1-2, pp 39-50.

[7]Amy Roth-McDuffie, J. Randy McGinnis, Anna O. Graeber: Perceptions of Reform-Based Teaching and Learning in a College Mathematics Class; Journal of Mathematics Teacher Education (10-2000) Volume 3, Issue 3, pp 225-250.

[8]Charles J. Eick, Bethany Stewart: Dispositions Supporting Elementary Interns in the Teaching of Reform-Based Science Materials; Journal of Science Teacher Education (05 Jan 2010)Volume 21, Issue 7, pp 783-800.

[9]Ali S. Al-Issa, Ali H. Al-Bulushi: English language teaching reform in Sultanate of Oman: The case of theory and practice disparity; Educational Research for Policy and Practice (June 2012) Volume 11, Issue 2, pp 141-176.

[10]Hans-Joachim Vollrath: Towards an authentic teaching of mathematics: Hans-Georg Steiner's contribution to the reform of mathematics teaching; ZDM (March 2007) Volume 39, Issue 1-2, pp 39-50. 